\title{
Cloning of a gene encoding an antigen associated with the centrosome
} in Drosophila

\author{
W. G. F. WHITFIELD' ${ }^{\prime}$, S. E. MILLAR ${ }^{1} * *$, H. SAUMWEBER ${ }^{2} \uparrow$, M. FRASCH ${ }^{2} \dagger$ and D. M. GLOVER \\ 'Cancer Research Campaign, Eukaryotic Molecular Genetics Research Group, Department of Biochemistry, Imperial College of Science and \\ Technology, London SW7 2AZ, UK \\ ${ }^{2}$ Max-Planck-Institut fïr Entzoicklungsbiologie, Spemanstrasse 35, Tübingen, FRG \\ * Present address: Laboratory of Cellular and Developmental Biology, Building 6, Room B1-08, National Institute of Diabetes and \\ Digestive and Kidney Discases, Bethesda, MD 20892, USA \\ †Present address: Institut für Entwicklungsphysiologie, Gyrhofstrasse 17, Köln, FRG \\ fPresent address: Department of Biological Sciences, Fairchild Center, Columbia University, New York, NY 10027, USA
}

\section{Summary}

The monoclonal antibody Bx63 recognizes a centrosomal antigen of Drosophila melanogaster by indirect immunofluorescence and identifies two proteins, with apparent molecular weights of $185 \times 10^{3}$ and $66 \times 10^{3}$, on Western blots. We have used this antibody to isolate five clones ( $\lambda$ cs $1,-2$, $-3,-4$ and $\lambda \mathbf{j 6 3}$ ) from $\lambda$ gt11 expression libraries of Drosophila DNA. Using polyclonal anti-centrosomal sera raised against both immunoaffinitypurified Bx63 antigen and electrophoretically purified fusion protein from clone $\lambda \operatorname{cs} 3$, we have demonstrated that the fusion proteins encoded by four of these clones ( $\lambda c s 1-4)$ share at least two epitopes with the $185 \times 10^{3} M_{\mathrm{r}}$ centrosomal antigen. This indicates that clones $\lambda$ cs $1-4$ contain DNA from the gene coding for this protein. The four clones are independent isolates from a single chromosomal site, which we show by in situ hybridization to correspond with salivary gland chromosome region 88E 4-8. A low-abundance transcript of approximately $4.0 \times 10^{3}$ bases corresponding to the cloned gene is detected in all stages of the Drosophila life-cycle.

Key words: Drosophila, mitosis, centrosomes, $\lambda \mathrm{gt} 11$ libraries, antibody screening, cloned DNAs.

\section{Introduction}

Many vital cellular processes are dependent on the proper organization and function of complex microtubular structures. The major microtubule-organizing centre of most animal cells is the centrosome, which is found at each pole of the mitotic spindle in dividing cells and at the focus of microtubule asters during interphase. Electron microscopy has shown that the centrosome consists of a pair of centrioles surrounded by densely staining amorphous material (Robbinset al. 1968). Microtubules appear to originate in this pericentriolar material and do not make contact with the centrioles (Gould \& Borisy, 1977). Although the centrosome has been shown to nucleate microtubule growth both in vitro and in vivo (Gould \& Borisy, 1977; Frankel, 1976; Osborne \& Weber, 1976; Mitchison \& Kirschner, 1984), various studies have indicated Journal of Cell Science 89, 467-480 (1988) Printed in Great Britain (C) The Company of Biologists Limited 1988 that centrioles are not required for mitosis or meiosis (Calarco-Gillam et al. 1983; Brenner et al. 1977; Debec et al. 1982). Their role in the organization and replication of the centrosome is therefore unclear. The capacity of the centrosome for microtubule nucleation has been shown to vary during the cell cycle (Snyder \& McIntosh, 1975; Kuryama \& Borisy, 1981). The amount of pericentriolar material at the centrosome also varies during the cell cycle (Robbins et al. 1968; Vorobjev \& Chentsov, 1982), but whether this variation represents a cause or an effect of altered nucleation capacity is unknown.

Attempts to isolate and characterize the pericentriolar material have been hampered by difficulties in obtaining sufficient quantities of material. However, the discovery of cell lines that contain multiple centrioles (Ring et al. 1980) has facilitated the preparation of functional centrosomes for use in studies of the 
nucleation process in vitro (Mitchison \& Kirschner, 1984). Similar preparations of functional centrosomes have been made from a human T-lymphoblastic cell line and their protein composition has been analysed (Gosti-Testu et al. 1986). Most approaches to the isolation of centrosomal proteins have used anti-centrosomal sera (Connolly \& Kalnins, 1978; Calarco-Gillam el al. 1983; Gosti-Testu et al. 1986) or monoclonal antibodies (Kuriyama \& Borisy, 1985) to identify centrosomal antigens. It is known that certain proteins, such as cyclic-AMP-dependent protein kinase (type II) (Nigg et al. 1985), are associated with the centrosome, but none of the centrosomal proteins that have been described to date have been proved to have a direct involvement in microtubule nucleation.

The Drosophila melanogaster embryo is ideal for the investigation of the biology of mitosis. Drosophila embryos undergo 13 nuclear divisions during the first $2 \mathrm{~h}$ of development. The last four mitoses prior to cellularization at division 14 occur at the cortex of the embryo and these blastoderm stages are therefore ideal for the observation of components of the mitotic apparatus by immunofluorescence (Warn et al. 1980; Fuchs et al. 1983; Karr \& Alberts, 1986; Frasch et al. 1986) and electron microscopy (Stafstrom \& Staehelin, 1984).

A monoclonal antibody Bx63 that specifically recognizes centrosomes in Drosophila has been described (Frasch, 1985; Frasch et al. 1986). This antibody has been used in studies of several mitotic mutants of Drosophila to investigate the behaviour of centrosomes (Freeman et al. 1986; Freeman \& Glover, 1987; Sunkel \& Glover, 1987). These studies identified genes essential for mitosis in Drosophila and led to strategies for gene cloning using well established approaches of chromosome walking or transposon tagging. An alternative approach to the isolation of genes involved in mitosis is offered by using antibodies to screen expression libraries in Escherichia coli. We have used the monoclonal antibody Bx63 to screen libraries of Drosophila DNA in the expression vector $\lambda \operatorname{gt} 11$, and we demonstrate that the clones identified contain DNA from a gene encoding a protein associated with the centrosome in Drosophila.

\section{Materials and methods}

\section{Antibodies}

Monoclonal antibody Bx63 is one member of a panel of monocional antibodies raised against nuclear proteins of 1-15 h embryos of D. melanogaster (Frasch, 1985).

Antiserum F72 was raised against a mixture of polypeptides derived from low-salt/Triton X-100 extracts of $1-16 \mathrm{~h}$ embryos of Drosophila by affinity chromatography on a B.63. antibody/Sepharose column. Balb/c mice were immunized by intraperitoneal injection of approximately $50 \mu \mathrm{g}$ of protein in $0.2 \mathrm{ml}$ of an emulsion of phosphate-buffered saline (PBS; $0 \cdot 16 \mathrm{M} \cdot \mathrm{NaCl}, 50 \mathrm{~mm}$-sodium phosphate buffer $(\mathrm{pH} 7 \cdot 0))$ and complete Freund's adjuvant $(1: 2, \mathrm{v} / \mathrm{v})$. Further injections of $50 \mu \mathrm{g}$ of protein with incomplete Freund's adjuvant were administered 21 and 35 days later. Serum was obtained from tail bleeds taken 7 days after the booster injections.

Antiserum Rb188 was raised against electrophoretically purified $\beta$-galactosidase fusion protein derived from crude cell lysates of pURcs3-transformed $E$. coli (strain BMH7118). A rabbit was immunized by subcutaneous injection of approximately $100 \mu \mathrm{g}$ of fusion protein in $0.6 \mathrm{ml}$ of an emulsion of PBS and complete Freund's adjuvant $(1: 2, v / v)$. Booster injections containing $100 \mu \mathrm{g}$ of fusion protein in incomplete Freund's adjuvant were administered 28 days and 56 days later. Blood was removed from the marginal vein of the ear 7 days after the first booster injection and the rabbit bled out and killed 7 days after the second booster. Serum was stored at $-70^{\circ} \mathrm{C}$ until use.

Monoclonal antibody $\mathrm{B} \times 63$ tissue culture supernatant was used at a dilution of 1 in 5 both for immunostaining of Western blots and for immunofluorescence microscopy. Antisera F72 and Rb188 were used at a dilution of 1 in 400 for all experiments. All second antibodies were obtained from Jackson Immunoresearch Laboratories Inc. (USA), peroxidase- and rhodamine-conjugated second antibodies were used at dilutions of $1 \mathrm{in} 1000$ and 1 in 500, respectively.

\section{Fixation and devitellinization of embryos}

Embryos were fixed and prepared for staining using a minor modification of the method of Dequin et al. (1984), which is based on the technique of Mitchison \& Sedat (1983). Embryos were dechorionated in $60 \%$ hypochlorite bleach in $0.7 \% \mathrm{NaCl}, 0.1 \%$ Triton $\mathrm{X}-100$ and then rinsed several times in a large volume of $\mathrm{NaCl} /$ Triton. After draining and blotting dry on tissue paper the embryos were transferred to a $50 \mathrm{ml}$ polypropylene tube containing $0.1 \mathrm{ml}$ of $37 \%$ formaldehyde (Fisons Scientific, UK), $0.4 \mathrm{ml}$ water, $0.1 \mathrm{ml} 10 \times$ buffer B (100 mM-potassium phosphate buffer (pH 6.8), $450 \mathrm{mM}-\mathrm{KCl}, 150 \mathrm{mM}-\mathrm{NaCl}, 20 \mathrm{mM}-\mathrm{MgCl}_{2}$ ), and $9 \mathrm{ml}$ of heptane. The tube was shaken vigorously for $10 \mathrm{~min}$ before adding an equal volume of methanol and shaking for a further 1 min. The emulsion that results gradually separates into two phases: embryos that have lost their vitelline membrane sink to the bottom of the tube, whereas the rest remain at the heptane/methanol interface. The liquid and floating embryos were then removed by aspiration and the devitellinized embryos rinsed twice with methanol for a total of $10 \mathrm{~min}$. The embryos were then equilibrated in $3 \times 10-\mathrm{ml}$ changes of buffer A $(15 \mathrm{~mm}$-Tris $\cdot \mathrm{HCl}(\mathrm{pH} 7 \cdot 4), 60 \mathrm{~mm}-\mathrm{KCl}, 15 \mathrm{~mm}-\mathrm{NaCl}$, $1.5 \mathrm{~mm}$-spermine, $0.5 \mathrm{~mm}$-spermidine) plus $0.1 \%$ Triton $\mathrm{X}-100$ for at least $1 \mathrm{~h}$ before staining.

\section{Antibody staining of embryos}

Approximately 200 embryos were transferred to $1.5 \mathrm{ml}$ microfuge tubes containing $0.5 \mathrm{ml}$ of $10 \%$ foetal calf serum (FCS) in buffer $A$. After incubation for $1 \mathrm{~h}$ at room temperature (or overnight at $4^{\circ} \mathrm{C}$ ), the supernatant was removed with a fine-drawn Pasteur pipette, and the embryos incubated in $1.4 \mathrm{ml}$ of first antibody diluted in $10 \% \mathrm{FCS} /$ buffer $\mathrm{A} / 0.1 \%$ Triton $X-100$, for $3-4 \mathrm{~h}$ at room temperature. The first antibody was then removed and the embryos given five 5-min 
washes in buffer $A$ plus $0.1 \%$ Triton $\mathrm{X}-100$, before incubating in second antibody diluted in $10 \% \mathrm{FCS} /$ buffer $\mathrm{A} / 0.1 \%$ Triton $\mathrm{X}-100$, for $3 \mathrm{~h}$ at room temperature. At the end of this incubation the embryos were washed in four changes of buffer $A / T$ Triton for at least $2 \mathrm{~h}$ in total. Two further brief rinses in buffer $A$ without Triton were given prior to incubating the embryos in buffer $A$ containing $1 \mu \mathrm{g} \mathrm{ml}^{-1}$ of Hoechst 33258. The stained embryos were mounted in $85 \%$ glycerol containing $2.5 \% n$-propylgallate (Giloh \& Sedat, 1982). Slides were viewed using a Nikon Microphot FX microscope with epifluorescence optics and appropriate filters for Hoechst and rhodamine. Embryos were photographed on Kodak 2415 technical film and developed with Kodak D-19 developer.

\section{Affinity chromatography}

Monoclonal antibody $\mathrm{Bx} 63$ was covalently coupled to protein A/Sepharose CL-4B (Sigma Chemical Co.) according to a modification of the method of Schneider et al. (1982), described by Simanis \& Lane (1985). Briefly, $1 \mathrm{ml}$ of Bx63 ascites fluid diluted in $9 \mathrm{ml}$ of $0.2 \mathrm{M}$-sodium borate buffer ( $\mathrm{pH} 8.0$ ) was mixed end-over-end with $1 \mathrm{ml}$ of pre-swollen protein $A /$ Sepharose for $1 \mathrm{~h}$ at room temperature. After extensive washing with $0 \cdot 1 \mathrm{M}$-borate buffer ( $\mathrm{pH} 9 \cdot 0$ ) the Sepharose was rinsed once in $0 \cdot 1 \mathrm{M}$-sodium borate buffer ( $\mathrm{pH} 9.0$ ) and resuspended in $10 \mathrm{ml}$ of borate buffer ( $\mathrm{pH} 9.0$ ), $50 \mathrm{mg}$ of dimethylpimilimidate (Sigma Chemical Co.) was added and the suspension mixed end-over-end for $l \mathrm{~h}$ at room temperature. The reaction was terminated by rinsing the Sepharose with $10 \mathrm{ml}$ of $40 \mathrm{~mm}$-ethanolamine ( $\mathrm{pH} 8.0$ ) followed by $0 \cdot 1 \mathrm{~m}$-borate buffer $(\mathrm{pH} 8 \cdot 0)$, in which it was stored at $4^{\circ} \mathrm{C}$ until required.

Embryos were collected on yeasted grape juice/agar plates from $D$. melanogaster population cages for a period of $16 \mathrm{~h}$. The embryos were harvested and washed several times in PBS containing $0.1 \%$ Triton $X-100$. After a further wash in PBS/Triton diluted $1: 9(\mathrm{v} / \mathrm{v})$ with water the embryos were rinsed in homogenization buffer ( $1 \mathrm{mM}$-Tris $\cdot \mathrm{HCl}(\mathrm{pH} 8 \cdot 0)$, $2 \mathrm{~mm} \cdot \mathrm{Na}_{2} \mathrm{EDTA}, \quad 1 \mathrm{~mm}$-phenylmethylsulphonyl fluoride (PMSF), $0.5 \%$ Triton X-100), drained, and transferred to a pre-cooled glass homogenizer (type B, Jencons Scientific Ltd). The embryos were homogenized in three times their own volume of ice-cold homogenization buffer using 20 strokes of the pestle, then centrifuged for $20 \mathrm{~min}$ at 10000 revs $\min ^{-1}$ in a Sorvall $\mathrm{HB}-4$ swing-out rotor at $2^{\circ} \mathrm{C}$. The clear supernatant was recovered from the pellet with as little contaminating lipid as possible, and $5 \mathrm{M}-\mathrm{NaCl}, 1 \mathrm{M}$ Tris $\cdot \mathrm{HCl}(\mathrm{pH} 8 \cdot 0)$ added to final concentrations of $0 \cdot 1 \mathrm{M}$ and $0.05 \mathrm{M}$, respectively. The supernatant was then recentrifuged as before and the second supernatant recycled three times through a $1 \mathrm{ml} \mathrm{B \times 63-antibody/Sepharose} \mathrm{column} \mathrm{at} \mathrm{a} \mathrm{flow}$ rate of approximately $1 \mathrm{ml} \mathrm{min}-1$. The column was washed with $50 \mathrm{ml}$ of $0 \cdot 1 \mathrm{M}-\mathrm{NaCl}, 0 \cdot 05 \mathrm{M}-$ Tris $\cdot \mathrm{HCl}$ (pH 8.0), $1 \mathrm{mM}$ PMSF, $0.1 \%$ Triton $\mathrm{X}-100$, followed by $50 \mathrm{ml}$ of $0.01 \mathrm{M}$ $\mathrm{NaCl}, 0 \cdot 005 \mathrm{M}-$ Tris $\cdot \mathrm{HCl}(\mathrm{pH} 8 \cdot 0), 1 \mathrm{~mm}$-PMSF. Bound material was eluted with $20 \mathrm{~mm}$-triethylamine (unbuffered) in $10 \%$ glycerol and recovered by precipitation with 2 vol. of absolute ethanol at $-20^{\circ} \mathrm{C}$.

\section{Electrophoresis and Western blotting}

Protein samples were analysed on $8.5 \%$ SDS-polyacrylamide gels (Laemmli, 1970). Gels were either fixed and stained in $25 \%$ isopropanol, $10 \%$ acetic acid, $0.2 \%$ Coomassie Blue R250, or electrophetically transferred to nitrocellulose filters in a Biorad Transblot apparatus according to the method of Towbin et al. (1979), except that methanol was not added to the transfer buffer. Filters were incubated overnight at $4^{\circ} \mathrm{C}$ in $10 \% \mathrm{FCS}$ in PBS, rinsed in PBS and then incubated for $2 \mathrm{~h}$ at room temperature in sealed polythene bags containing the first antibody diluted in $10 \% \mathrm{FCS} / \mathrm{PBS}$. After washing the filters for $15 \mathrm{~min}$ in each of the following: (1) $1 \%$ NP40 in PBS, (2) $0.1 \%$ NP40 in PBS and (3) PBS alone, they were then resealed in polythene bags containing peroxidase-conjugated second antibody diluted 1 to 1000 in $10 \% \mathrm{FCS} / \mathrm{PBS}$ and incubated at room temperature for $2 \mathrm{~h}$. The washing cycle was repeated, including an extra wash in PBS before developing the staining in a filtered solution of $0.05 \%$ 4-chloro-1-naphthol (Aldrich Chemical Company Ltd) in PBS to which 0.0002 vol. of $\mathrm{H}_{2} \mathrm{O}_{2}(30 \%$, w/v) had been added.

Samples of total protein from embryos of Drosophila were prepared by homogenization of approximately 1000 embryos in $0.5 \mathrm{ml}$ of ice-cold gel sample buffer ( $2 \%$ SDS, $0.125 \mathrm{M}$ Tris $\cdot \mathrm{HCl}(\mathrm{pH} \mathrm{6.9)}, 5 \%$ 2-mercaptoethanol, $10 \%$ glycerol). Immediately after homogenization samples were heated on a boiling water bath for $5 \mathrm{~min}$ and then centrifuged in a microfuge (Eppendorf) for $1 \mathrm{~min}$ to pellet insoluble material. Samples were either used immediately or stored frozen at $-20^{\circ} \mathrm{C}$

\section{Bacterial strains, vectors and enzymes}

E. coli strains Y1090 and Y1089, and phage $\lambda$ gt 11 have been described by Young \& Davis $(1983 a)$. E. coli strain BMH7118 has been described by Messing et al. (1977) and plasmid pUR290 by Rüther \& Müller-Hill (1983). Restriction enzymes and bacteriophage $\mathrm{T} 4$ ligase were obtained from Boehringer-Mannheim.

\section{Expression libraries}

The $D$. melanogaster third instar larval cDNA library in $\lambda \mathrm{gt} 11$ was produced as described by Millar (1987). The $D$. melanogaster genomic DNA library in $\lambda$ gtll was kindly provided by $\mathrm{Dr} M$. Wilcox and was originally made by $\mathrm{Dr} G$. Pflugfelder from randomly sheared D. melanogaster DNA.

\section{Screening of plaques}

Approximately $7 \cdot 5 \times 10^{4}$ plaque-forming units per $15 \mathrm{~cm}$ plate were plated on a lawn of Y1090 (Young \& Davis, 1983b) in soft agar on $\mathrm{LB}$ agar containing $10 \mathrm{~mm}-\mathrm{MgCl}_{2}$. After incubation at $42^{\circ} \mathrm{C}$ for $3 \mathrm{~h}$ the plates were removed to $37^{\circ} \mathrm{C}$ and overlayered with isopropylthiogalactoside IPTG-treated nitrocellulose filters. (Filters were soaked in $10 \mathrm{~mm}-\mathrm{IPTG}$ and blotted dry on filter paper just prior to use.) The orientation of the filters was marked using a needle dipped in India ink. Plates were incubated for $3 \mathrm{~h}$ at $37^{\circ} \mathrm{C}$ before carefully removing the filters, and were stored at $4^{\circ} \mathrm{C}$ whilst the filters were processed. 
Filters were rinsed briefly in PBS and immunostained essentially as described for Western blots. Antibody incubations were carried out in plastic Petri dishes, with continuous agitation. Periodically, during incubations, filter stacks were rotated top to bottom to ensure even contact of antibody solution with all filters. The colour reaction was developed until contrast between positive signals and background staining was judged to be no longer increasing. Filters were then rinsed several times in water to stop the reaction. Phage plaques giving positive signals were picked using the wide end of a Pasteur pipette and successively rescreened to purify recombinants.

\section{Production of fusion protein from $\lambda \mathrm{gt} 1 \mathrm{l}$ clones}

Lysogens of $\lambda$ gt 11 recombinants were made by infecting the host Y1089 at a multiplicity of infection of $>5$ and plating at $30^{\circ} \mathrm{C}$ on LB/ampicillin agar plates. Colonies were regridded and tested for growth at $30^{\circ} \mathrm{C}$ and $42^{\circ} \mathrm{C}$ to identify lysogens (lysogens will not grow at $42^{\circ} \mathrm{C}$ ). Protein samples from induced lysogens were prepared as described by Huynh et al. (1985).

Fusion proteins were also produced from subclones of $\lambda$ gt 11 inserts in the plasmid vector pUR290. The $\lambda g t 11$ inserts were excised with $E c o R I$ and ligated into the natural EcoRI site in the lac $Z$ gene of pUR290. Competent cells ( $E$. coli strain BMIH71-18) were transformed using standard methods, and in-frame recombinants selected by screening IPTG-induced colonies with $\mathrm{B} \times 63$ antibody as follows: ampicillin-resistant colonies were regridded in duplicate onto two LB/ampicillin plates, one plate having an IPTG-soaked nitrocellulose filter overlay, and incubated at $37^{\circ} \mathrm{C}$ until small colonies were visible. Colonies on the nitrocellulose filter were then lysed by placing the filter on a layer of filter paper moistened with $1 \%$ SDS and baking at $80^{\circ} \mathrm{C}$ for $10 \mathrm{~min}$. Proteins were fixed to the nitrocellulose by electroblotting (colonies cathodal to the filter) in the Biorad Transblot apparatus for $30 \mathrm{~min}$ at $80 \mathrm{~V}$, using a $25 \mathrm{~mm}$-Tris $/ 193 \mathrm{~mm}$ glycine (pH 8.5) buffer. Filters were rinsed and immunostained as described for Western blots, and colonies giving positive signals were recovered from the duplicate plate. Samples of fusion protein were prepared from IPTG. induced overnight cultures of positive colonies. Cells were harvested by centrifugation, cell pellets raised in SDS sample buffer ( 1 vol. per 5 vol. of original culture), and freezethawed in solid $\mathrm{CO}_{2}$ /ethanol before heating on a boiling water bath for $5 \mathrm{~min}$. Samples were stored at $-20^{\circ} \mathrm{C}$ until use.

\section{Purification of fusion proteins}

Samples of fusion protein in SDS sample buffer were separated by preparative electrophoresis on $6 \%$ SDSpolyacrylamide gels (approximately $4 \mathrm{mg}$ of protein was loaded on a $14 \mathrm{~cm}$ wide, $3 \mathrm{~mm}$ thick slab gel). The strip containing the fusion protein was excised and transferred to dialysis tubing containing a small volume of SDS/Tris/glycine electrophoresis buffer. Fusion protein was electroeluted from the gel strip at $150 \mathrm{~V}$ for $4 \mathrm{~h}$, in a flat-bed gel apparatus containing sufficient electrophoresis buffer to cover the dialysis tubing (polarity was reversed for the final minute of elution). Purified fusion protein was recovered by precipitation with ethanol and stored at $-20^{\circ} \mathrm{C}$.

\section{Affinity purification of antibodies}

Fusion protein was separated on SDS-polyacrylamide gels and electrophetically transferred to nitrocellulose. The fusion protein band was located by temporary staining of the filter with $0.2 \%$ Ponceau S in $3 \%$ trichloroacetic acid and excised with a scalpel blade. The filter strip was then blocked, incubated with first antibody and washed, as described for Western blots. Bound antibodies were eluted from the strip with $0.5 \mathrm{ml}$ of $20 \mathrm{~mm}$-triethylamine (unbuffered) in $10 \%$ glycerol, $0.1 \mathrm{ml}$ of $1 \mathrm{M}$-Tris $\cdot \mathrm{HCl}(\mathrm{pH} 7.5)$ and $0.2 \mathrm{ml}$ of FCS were added to the eluate, which was used for immunostaining of embryos and Western blots without further dilution.

\section{Analysis of RNA and DNA}

Electrophoresis of RNA was performed in $1 \%$ agarose gels containing 2.2 M-formaldehyde (Rave et al. 1979), gels were transferred to nitrocellulose as described by Thomas (1980). Electrophoresis of DNA was performed in $0.8 \%$ agarose gels containing $40 \mathrm{~mm}$-Tris $\cdot \mathrm{HCl}(\mathrm{pH} 8 \cdot 3), 20 \mathrm{~mm}$-sodium acetate and $2 \mathrm{~mm}-\mathrm{Na}_{2}$ EDTA. Gels were stained with $1 \mu \mathrm{gml^{-1 }}$ ethidium bromide and transferred to nitrocellulose by capillary blotting (Southern, 1975). Probes were radiolabelled with ${ }^{32} \mathrm{P}$ by the oligo-labelling method (Feinberg $\&$ Vogelstein, 1983,1984 ), and were hybridized to DNA blots at $68^{\circ} \mathrm{C}$ in a solution containing $0.1 \% \mathrm{SDS}, 1 \%$ low-fat milk powder, $5 \times \mathrm{SSC}$ ( $\mathrm{SSC}$ is $0.15 \mathrm{M}-\mathrm{NaCl}, 0.015 \mathrm{M}$-sodium citrate, $\mathrm{pH} \mathrm{7.0)}$ and $100 \mu \mathrm{g} \mathrm{ml}^{-1}$ sonicated salmon DNA. Blots were washed at room temperature in three changes of $0.1 \%$ SDS, $1 \times \mathrm{SSC}$, then in two changes of $3 \mathrm{~mm}-\mathrm{Tr}$ ris base (unbuffered). Blots were visualized by exposure at $-70^{\circ} \mathrm{C}$ to $\mathrm{X}$-ray film (Fuji RX) with an intensifying screen. Probes were hybridized to RNA blots at $42^{\circ} \mathrm{C}$ in a solution containing $0.75 \mathrm{M}$ $\mathrm{NaCl}, 0 \cdot 15 \mathrm{~m}-\mathrm{Tris} \cdot \mathrm{HCl}(\mathrm{pH} 8 \cdot 0), 10 \mathrm{mM}-\mathrm{Na}_{2}$ EDTA, $36 \mathrm{~mm}$ $\mathrm{Na}_{2} \mathrm{HPO}_{4}, 4 \mathrm{mM}-\mathrm{NaH}_{2} \mathrm{PO}_{4}, 0.5 \%$ SDS, $50 \%$ formamide, $5 \times$ Denhardt's (1966) reagent, and $200 \mu \mathrm{g} \mathrm{ml}^{-1}$ salmon DNA for $24-48 \mathrm{~h}$. After washing for several hours in $5 \times$ Denhardt's reagent in $0.3 \mathrm{M}-\mathrm{NaCl}, 0.06 \mathrm{M}-\mathrm{Tr}$ ris $\cdot \mathrm{HCl}(\mathrm{pH} 8 \cdot 0$ ), $4 \mathrm{~mm}-\mathrm{Na}_{2} \mathrm{EDTA}, 0.5 \%$ SDS, filters were washed for a further $30 \mathrm{~min}$ in two changes of $0.075 \mathrm{M}-\mathrm{NaCl}, 0.015 \mathrm{M}$ Tris $\cdot \mathrm{HCl}(\mathrm{pH} 8 \cdot 0), 1 \mathrm{~mm}-\mathrm{Na}_{2}$ EDTA, $0.5 \%$ SDS. Blots were visualized by exposure to $X$-ray film (Fuji $R X$ ) with an intensifying screen for 3 days at $-70^{\circ} \mathrm{C}$.

In situ hybridization to salivary gland polytene chromosomes was essentially as described by Pardue (1986), using ${ }^{3} \mathrm{H}$-labelled $\lambda \operatorname{cs} 3 \mathrm{DNA}$ as a probe. Hybridization was in $4 \times \mathrm{SSC}, 1 \times$ Denhardt's reagent, $10 \%$ dextran sulphate and $200 \mu \mathrm{g} \mathrm{ml}^{-1}$ denatured salmon DNA at $58^{\circ} \mathrm{C}$ for $16 \mathrm{~h}$. Slides were washed in three changes of $2 \times \mathrm{SSC}$ at $53^{\circ} \mathrm{C}$ over a period of $1 \mathrm{~h}$ before dehydrating in ethanol and processing for autoradiography.

\section{Results}

\section{Monoclonal antibody Bx63 binds to an antigen associated with the centrosome and identifies two proteins on Western blots of total protein extracts from Drosophila embryos}

The distribution of $\mathrm{Bx} 63$ antigen in whole-mount Drosophila embryos has been examined in detail using 

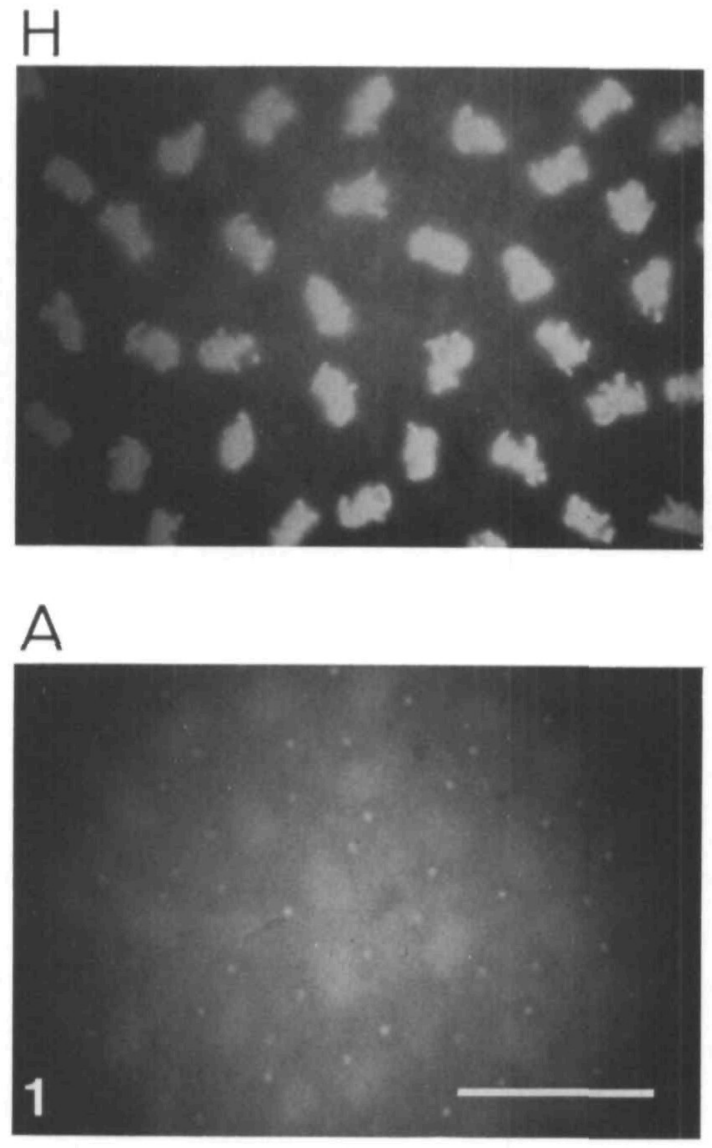

Fig. 1. Indirect immunofluorescence staining of a Drosophila embryo with monoclonal antibody Bx63. Embryos were incubated with Bx63 followed by rhodamine-conjugated anti-mouse IgG and the DNA fluorochrome Hoechst 33258. The Hoechst-stained field (H) shows metaphase chromosomes from a blastoderm embryo. The corresponding field stained with Bx63 (A) shows centrosomes at the spindle poles and faint staining of the mitotic spindle. Embryos immunostained with second antibody alone showed no detectable staining of centrosomes or nuclei. Bar, $20 \mu \mathrm{m}$.

immunofluorescence microscopy (Frasch, 1985; Frasch et al. 1986). Fig. 1 shows a typical example of the pattern of Bx63 staining observed at mitotic metaphase in early blastoderm embryos. In late blastoderm embryos the Bx63 antibody not only stains centrosomes, but also gives a diffuse staining of the interphase nucleus. This nuclear staining does not disperse at mitosis but persists in the region of the mitotic spindle (Frasch et al. 1986). In our experiments, the Bx63 antibody identified two proteins with apparent molecular weights of $185 \times 10^{3}$ and $66 \times 10^{3}$ in total protein extracts from Drosophila embryos (Fig. 2; lanes 5,6$)$. These correspond to the $185 \mathrm{~K}(\mathrm{~K}=$ $10^{3} M_{\mathrm{r}}$ ) band and $71 \mathrm{~K} / 69 \mathrm{~K}$ doublet described by Frasch (1985). Additional proteins with apparent molecular weights of approximately $120 \times 10^{3}$ and $58 \times 10^{3}$

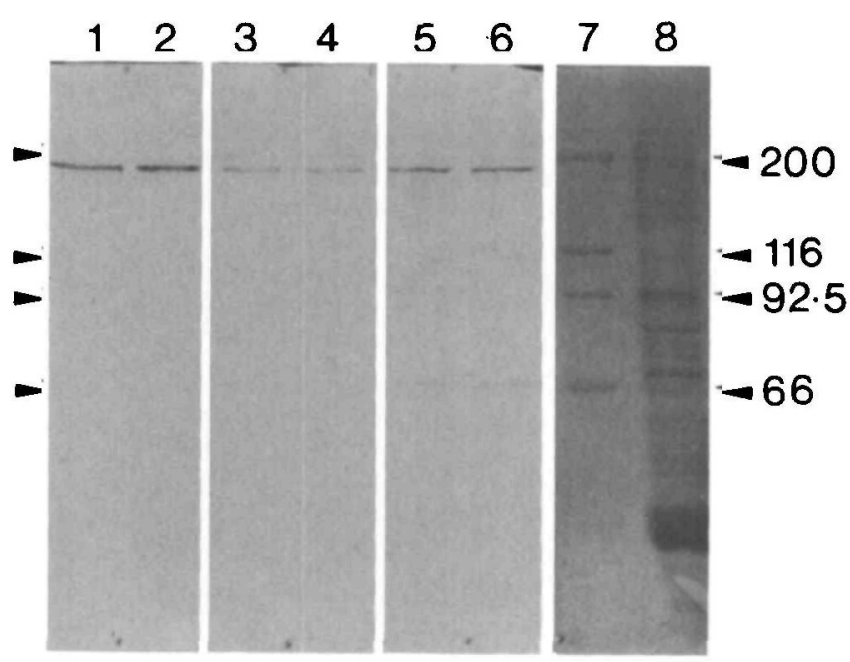

Fig. 2. Western blot analysis of total protein extract from Drosophila embryos. Protein from Drosophila embryos was separated on SDS-polyacrylamide gels and transferred to nitrocellulose filters. Lanes 1, 2, immunostained with polyclonal antiserum $\mathrm{Rb} 188$; lanes 3 , 4, with polyclonal antiserum F72; and lanes 5, 6, with monoclonal antibody Bx63, followed by the appropriate peroxidase-conjugated second antibody in each case. Bx63 staining reveals two polypeptides with approximate $M_{\mathrm{r}}$ values of $185 \times 10^{3}$ and $66 \times 10^{3}$. F72 reveals a $200 \mathrm{~K}$ and a $185 \mathrm{~K}$ polypeptide, but not a $66 \mathrm{~K}$ polypeptide. Rb188 reveals a single $185 \mathrm{~K}$ polypeptide. Lanes 7, 8, stained with Amido Black to show total protein. Filters immunostained with second antibody alone or pre-immune sera showed no detectable staining. Positions of $M_{\mathrm{r}}$ standards are indicated, $\times 10^{-3}$.

have been observed occasionally, and possibly result from proteolytic degradation.

In order to investigate the relationship between the $185 \mathrm{~K}$ and $66 \mathrm{~K}$ proteins recognized by the $\mathrm{Bx} 63$ antibody we endeavoured to prepare antisera that could distinguish one from the other. To this end, an enriched preparation of the Bx63 antigens was prepared from Drosophila embryos for use as an immunogen. Affinity chromatography of low-salt/Triton X-100 extracts of Drosophila embryos on a Bx63-antibody/ Sepharose column (see Materials and methods) yiclds a preparation showing a complex pattern of proteins on Coomassie Blue-stained SDS-polyacrylamide gels (Fig. 3; lanes 4, 5). Immunostaining of Western blots of the Bx63/Sepharose column eluate confirms that this preparation is enriched for both the $185 \mathrm{~K}$ and $66 \mathrm{~K}$ proteins (Fig. 3; lanes 1, 2, bands marked with filled circles). In addition, the antibody recognizes several other minor bands that are not normally observed on Bx63-stained blots of cleavage embryo extracts. These bands may be detectable only as a result of the enrichment process of affinity chromatography or, alternatively may result from proteolytic degradation of the $185 \mathrm{~K}$ and $66 \mathrm{~K}$ proteins during isolation. Several 


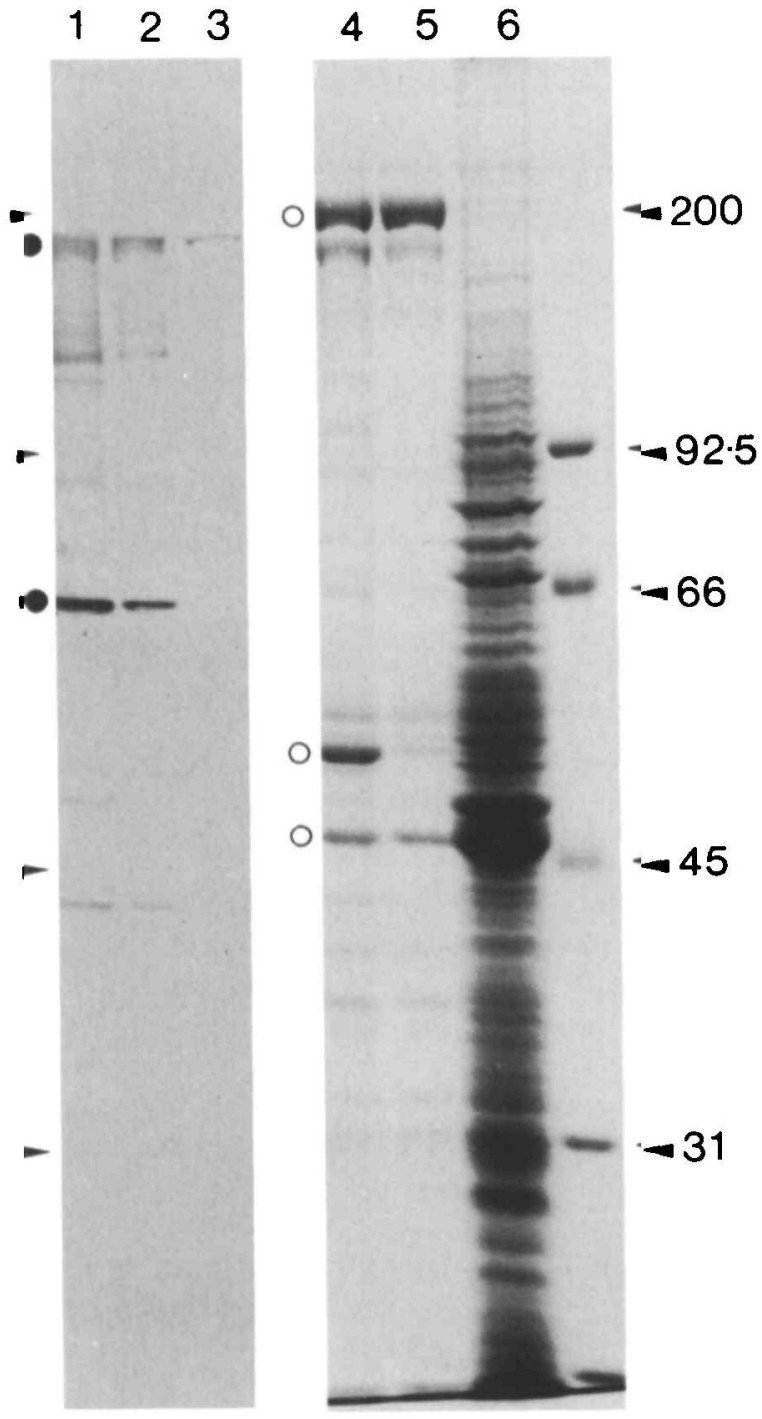

Fig. 3. SDS-polyacrylamide gel electrophoresis and Western blot analysis of Bx63-antibody/Sepharose-bound proteins. Low-salt/Triton X-100 lysates of Drososphila embryos were passed through a $1 \mathrm{ml}$ Bx63-antibody/ Sepharose column, after extensive washing, bound proteins were eluted at high $\mathrm{pH}$ and recovered by precipitation with ethanol. Lanes 1, 2, Western blots of bound proteins from two successive rounds of binding and elution; lane 3 , unbound material; all three lanes were immunostained with Bx63 antibody. Lanes 4-6, equivalent tracks from a Coomassie Blue-stained gel. The filled circles mark the usual position of $\mathrm{B} \times 63$ antigens detected in untreated extracts. The Coomassie-stained bands marked with open circles indicate three major polypeptides, co-isolating with the Bx63 antigens, that are not recognized by the Bx63 antibody. $M_{\mathrm{r}}$ standards are indicated, $\times 10^{-3}$.

other proteins that co-isolate with the $\mathrm{Bx} 63$ antigens are not recognized by the Bx63 antibody on Western blots. In particular, protein bands with molecular weights of 200,55 and $46\left(\times 10^{3}\right)$ are prominent (Fig. 3 ; lanes 4 , 5 , bands marked with open circles). A $0 \cdot 5 \mathrm{M}-\mathrm{LiCl}$ wash prior to elution from the Bx63/Sepharose column at high $\mathrm{pH}$ completely removes the $200 \mathrm{~K}$ protein, but the $55 \mathrm{~K}$ and $43 \mathrm{~K}$ proteins remain associated (results not shown). Whether or not these proteins are associated with the Bx63 antigens in vivo is not clear.

\section{Polyclonal antiserum F72 recognizes the $185 K$, but not the $66 \mathrm{~K} B \times 63$ antigen}

We have used the bound fractions from the Bx63antibody/Sepharose affinity column to immunize mice, and despite the complexity of the column cluate, the antiserum that we obtained (F72) shows a strong immune response to only two proteins with apparent molecular weights of 185 and $200\left(\times 10^{3}\right)$ (Fig. 2; lanes $3,4)$. When whole mounts of Drosophila embryos are examined by indirect immunofluorescence microscopy using F72 serum, we see staining of centrosomes and nuclei, in a pattern similar to but more intense than that found with the Bx63 antibody. This is illustrated in Fig. 4, which shows three fields of nuclei from different embryos at interphase, prophase and anaphase after staining with F72 serum and the DNA fluorochrome Hoechst 33258. At interphase (field 1) only one centrosome is visible in association with each nucleus, the centrosomes lie above diffusely stained regions that correspond to the position of the nuclei (cf. Hoechst stain). At prophase (field 2), two centrosomes are visible at a focal plane above that of each nucleus, whereas in other focal planes only nuclear staining is apparent. At anaphase (field 3), centrosomes are visible at the spindle poles, while the region of the spindle apparatus is only faintly stained. In addition, F72 serum gives a pattern of faint reticular staining in the cytoplasm of the blastoderm embryo, but only after cellularization has taken place. The reticular pattern is identical to that observed using a polyclonal serum raised against the $200 \mathrm{~K}$ protein that co-isolates with Bx63 antigens on Bx63-antibody/Sepharose affinity columns (data not shown). It seems probable, therefore, that the $185 \mathrm{~K}$ and $200 \mathrm{~K}$ proteins recognized by F72 serum on Western blots have a nuclear/centrosomal and reticular cytoplasmic distribution, respectively. The $66 \mathrm{~K}$ protein that is recognized on Western blots by Bx63 antibody is not, however, recognized by the F72 antiserum, demonstrating that the $185 \mathrm{~K}$ and $66 \mathrm{~K}$ proteins do not have extensive similarity.

\section{Isolation of DNA encoding Bx63 antigen}

In order to clone the gene, or genes, encoding the centrosomal/nuclear antigens, we have used the Bx63 antibody to screen expression libraries of both Drosophila genomic DNA (made by Dr G. Pflugfelder) and cDNA from third instar larvae (Millar, 1987) cloned in $\lambda$ gt11. These recombinants have the Drosophila DNA inserted in the natural EcoRI site of the lac $Z$ gene, such that coding regions inserted 

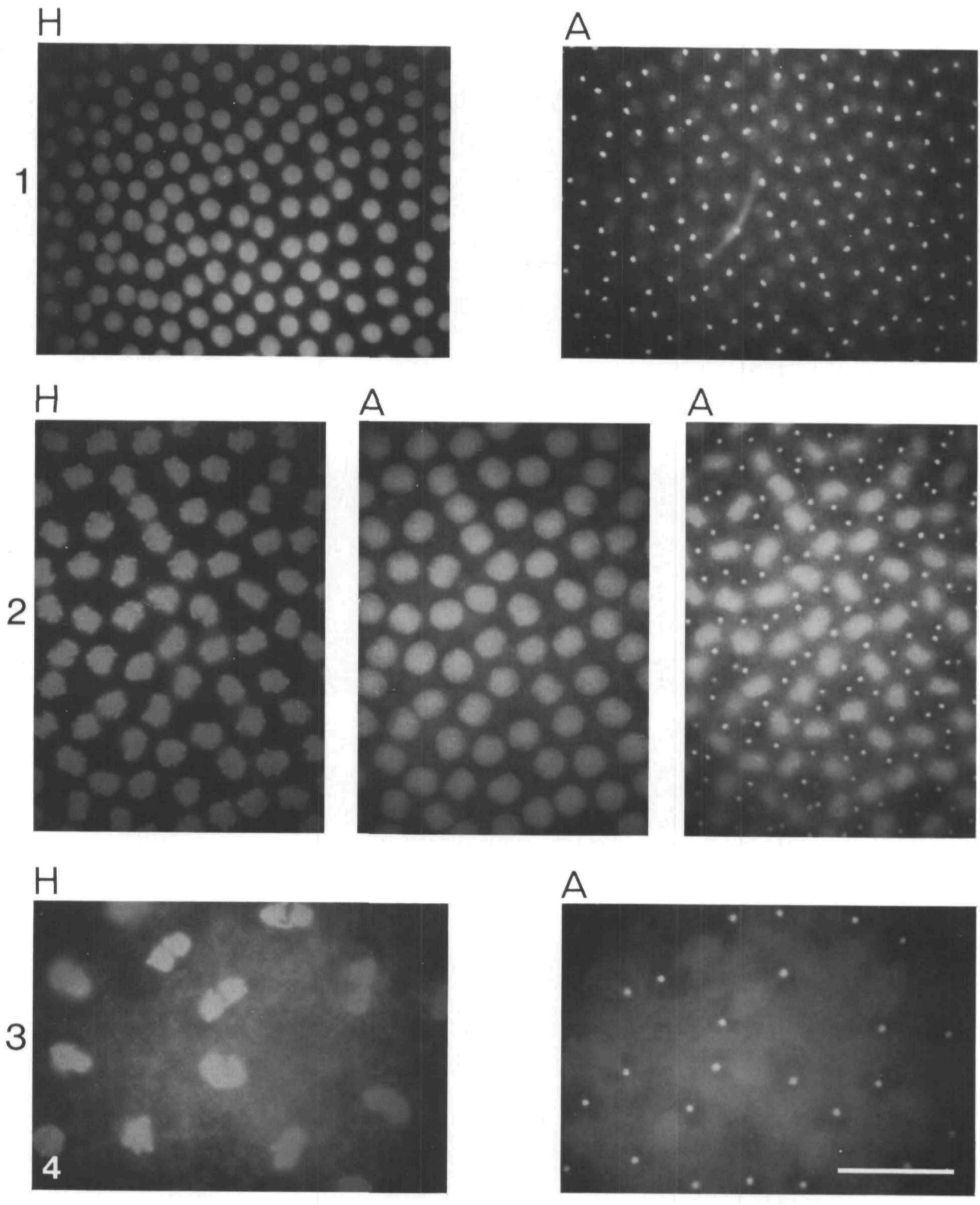

Fig. 4. Indirect immunofluorescence staining of Drosophila embryos with polyclonal antiserum F72. Embryos were incubated in antiserum F72 followed by rhodamine-conjugated anti-mouse IgG and Hoechst 33258. Three fields from different embryos are shown: field 1 at interphase; field 2 at prophase; and field 3 at anaphase, stained with Hoechst (H) and F72 antiserum (A). Antibody staining at interphase (field 1) reveals single centrosomes positioned above diffusely stained regions that correspond to interphase nuclei. At prophase (field 2), antibody staining is shown at two focal planes, the nuclei are diffusely stained and each nucleus has two associated centrosomes, which can be clearly seen above the nucleus at the higher focal plane. At anaphase (field 3), the antibody staining reveals centrosomes at the spindle poles while the region of the spindle apparatus is only faintly stained. Embryos immunostained with pre-immune serum showed no detectable staining of centrosomes or nuclei. Bar, $20 \mu \mathrm{m}$. 
in-frame with lac $Z$ will be expressed as $\beta$-galactosidase fusion proteins. The lac promoter is induced with isopropylthiogalactoside and the fusion proteins can be detected in the phage plaques using suitable antisera. We screened approximately $10^{6}$ phage carrying genomic DNA, from which we isolated four clones, $\lambda \mathrm{cs} 1$, $-2,-3$ and -4 . We also screened $1 \cdot 3 \times 10^{5}$ phage carrying cDNA made from 3rd-instar larval polyadenylated RNA from which we isolated a single clone, $\lambda_{j} 63$. Lysogenic strains of $E$. coli were established containing each of these recombinant prophage. In addition, the inserted Drosophila DNA from phages $\lambda \mathrm{cs} 3$ and $\lambda j 63$ were recloned into the plasmid expression vector pUR290 (Rüther \& Müller-Hill, 1983). The $\beta$-galactosidase fusion proteins produced from the resulting recombinant plasmids, pURcs 3 and pURj63, are essentially identical to the phage-encoded fusion proteins, but are expressed at a higher level. Fig. 5 shows a Western blot of total protein extracted from the lysogens, $E$. coli $(\lambda \operatorname{cs} 1-4)$, and the E. coli strain carrying pURj63, induced to express the fusion protein with IPTG. Lanes 1-5 are stained with monoclonal antibody $\mathrm{Bx} 63$, and in each case the fusion protein is recognized. The higher yield of fusion protein from the E. coli strain carrying pURj63 is apparent in lane 1 , in which the antibody is staining both the intact fusion protein and a number of proteolytic breakdown products.

The selection of recombinant phage from a $\lambda \mathrm{gt} 11$ library using a monoclonal antibody yields clones whose only proven relationship to the cellular antigen recognized by that antibody is the sharing of a single antigenic determinant. Furthermore, there are several reported instances of the fortuitous sharing of single antigenic determinants by different polypeptides (e.g. see Nigg et al. 1982). Consequently, we were concerned to find independent evidence that the clones isolated using Bx63 antibody do encode the centrosome-associated antigens. We therefore counterscreened the fusion proteins with the F72 serum (Fig. 5, lanes 6-10), and found that the fusion proteins produced by the clones $\lambda c s 1-4$ are recognized by this serum, whereas the pURj63 fusion protein is not. As the F72 serum stains the $185 \mathrm{~K}$, but not the $66 \mathrm{~K}$ Bx63 antigens on Western blots, it clearly does not recognize the Bx63 epitope and must therefore be recognizing other antigenic determinants on the $185 \mathrm{~K}$ protein. This evidence indicates that the Drosophila DNA in the clones $\lambda \mathrm{cs} 1-4$ encodes proteins that each share more than one antigenic determinant with the $185 \mathrm{~K}$ protein.

In order to relate the antigenic determinants on the $185 \mathrm{~K}$ protein and the fusion proteins to the immunofluorescent staining pattern of F72 serum, we affinitypurified antibodies against the pURcs 3 fusion protein from this serum. These antibodies, specific for the pURcs 3 fusion protein, recognize a $185 \mathrm{~K}$ protein on blots of total protein from embryos but no longer bind to the $200 \mathrm{~K}$ protein (Fig. 6). Indirect immunostaining of embryos with affinity-purified F72 antibodies gives results that are essentially identical to those using monoclonal antibody Bx63 (Fig. 7). This confirms that the $\mathrm{pURcs} 3$ fusion protein has epitopes, other than that recognized by the Bx63 monoclonal antibody, that are

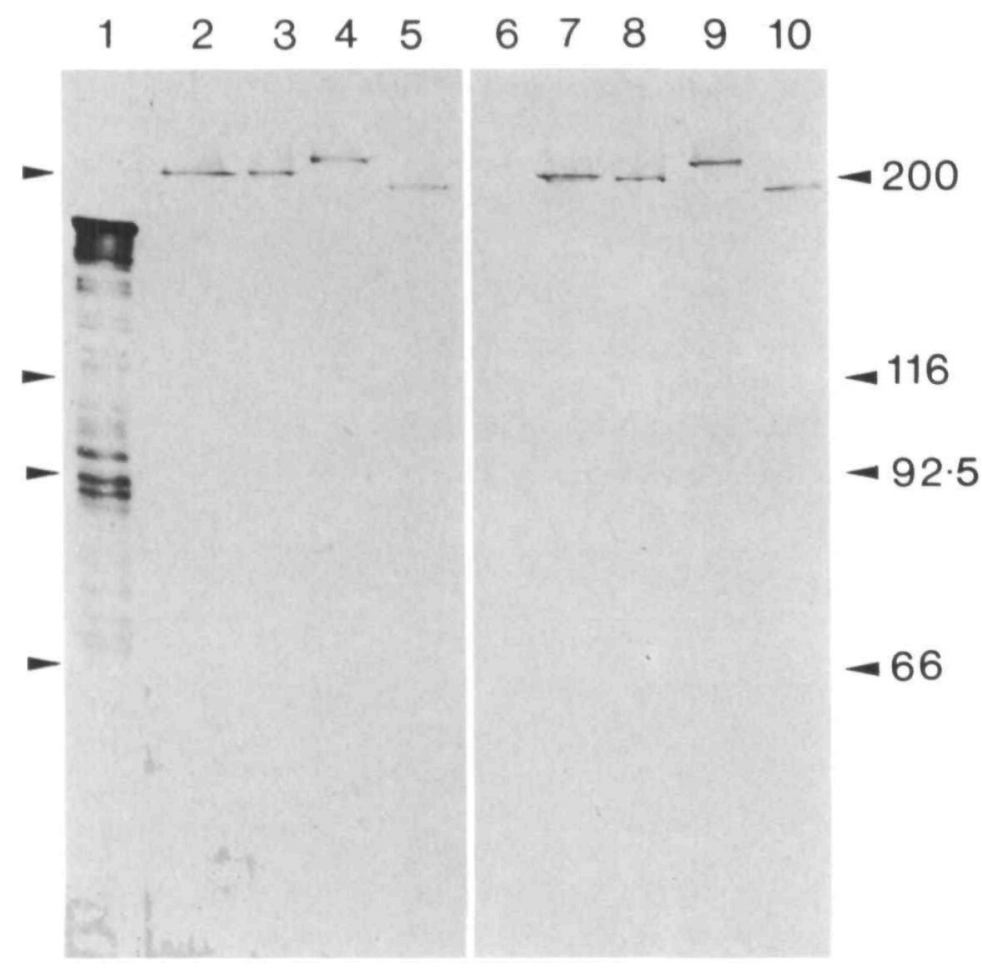

Fig. 5. Western blot analysis of fusion proteins derived from $\lambda \mathrm{gt} 11$ recombinant phage selected with monoclonal antibody Bx63. Lysates of $E$. coli containing $\beta$-galactosidase fusion proteins from clones pURj63, $\lambda \mathrm{cs} 1,-2,-3$ and -4 (lanes $1-5$, respectively) were separated on SDS-polyacrylamide gels and transferred to nitrocellulose filters. Lanes $1-5$, immunostained with monoclonal antibody $\mathrm{Bx} 63$, and a replica filter (lanes 7-10) was immunostained with antiserum F72. Note that the fusion proteins from clones $\lambda$ cs $1-4$ are recognized by both monoclonal antibody Bx63 and F72 serum, whereas the fusion protein from clone pURj63 is only recognized by Bx63. Positions of $M_{\mathrm{r}}$ standards are indicated, $\times 10^{-3}$. 


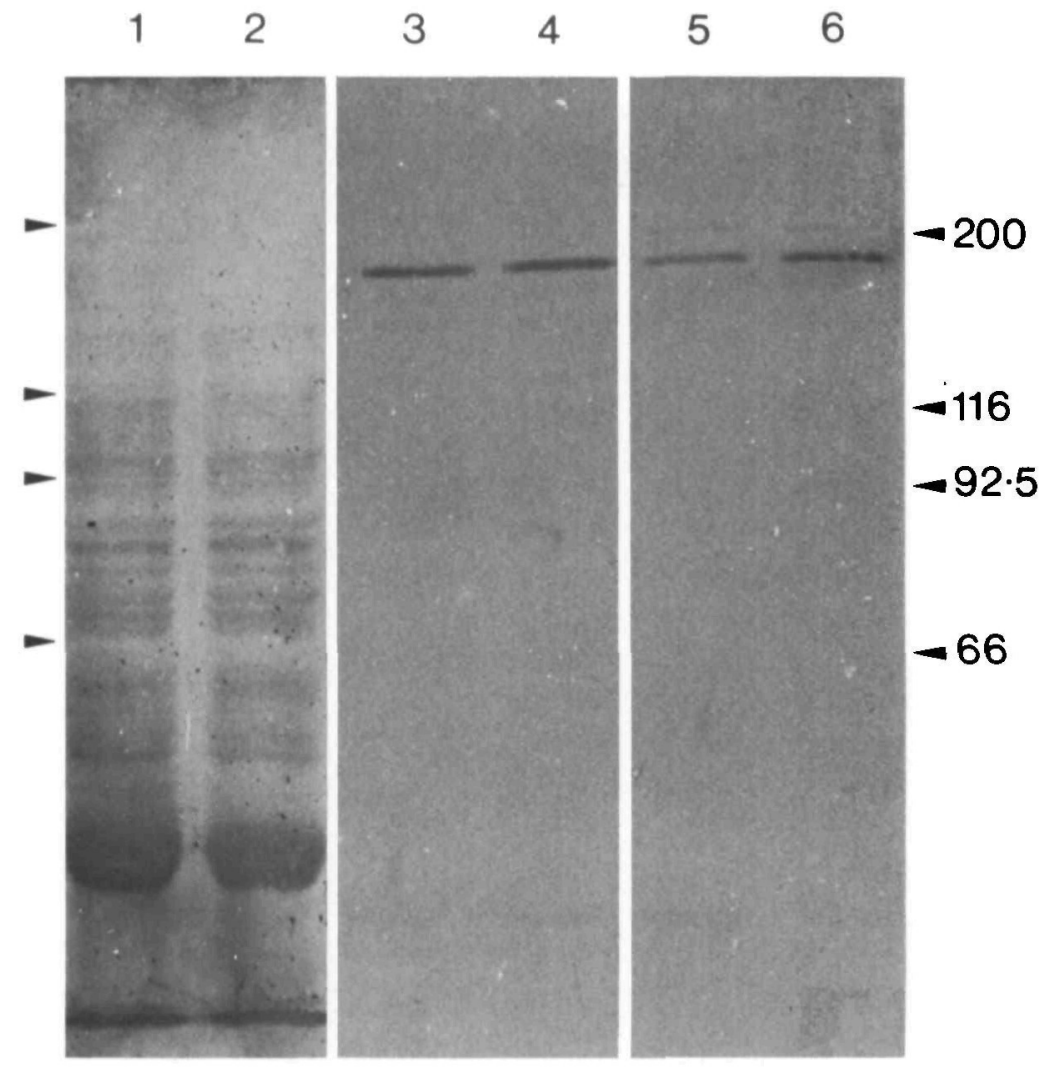

Fig. 6. Western blot of total protein extract from Drosophila embryos immunostained with affinity-purified F72 antiserum. Proteins from Drosophila embryos were separated on SDS-polyacrylamide gels and transferred to nitrocellulose filters. Lanes 1, 2, stained with Amido Black to show total protein. Lanes 3, 4, immunostained with F72 serum affinitypurified against fusion protein derived from clone $\lambda \operatorname{cs} 3$ (see Materials and methods); and lanes 5,6 , stained with untreated F72 serum. Note that the untreated F72 antiserum recognizes two polypeptides of $200 \mathrm{~K}$ and $185 \mathrm{~K}$ (lanes 5, 6), while the affinity-purified antibody only recognizes the $185 \mathrm{~K}$ polypeptide (lanes 3,4 ). Filters immunostained with antibodies affinitypurifed from F72 serum against unrelated proteins of $E$. coli showed no detectable staining. Positions of $M_{\mathrm{r}}$ standards are indicated, $\times 10^{-3}$.
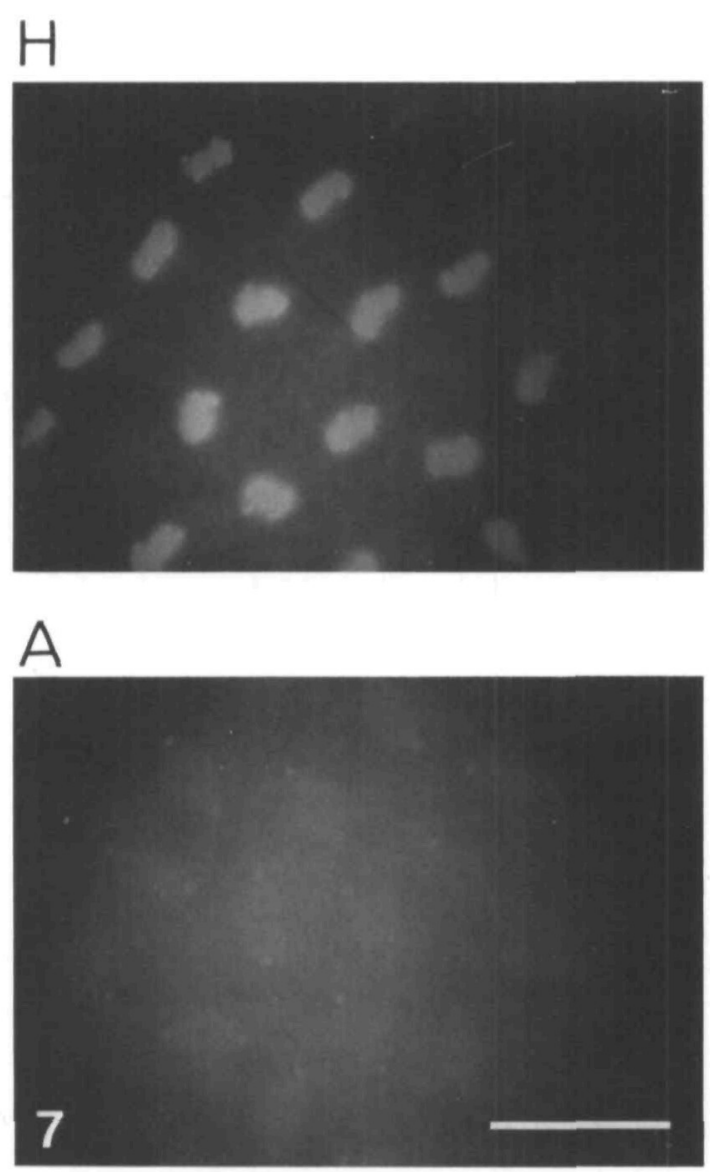

also present on the $185 \mathrm{~K}$ centrosomal/nuclear associated protein.

In order to provide additional confirmation of the relationships of the $p U R \operatorname{cs} 3$ and $p U R j 63$ fusion proteins to the Bx63 antigens, we electrophoretically purified these fusion proteins and raised antisera against them. The antiserum against the pURcs3 fusion protein, $\mathrm{Rb} 188$, recognized a $185 \mathrm{~K}$ protein on Western blots of total protein from Drosophila embryos (Fig. 2, lanes 1, 2), but, like F72 serum, it does not recognize a $66 \mathrm{~K}$ protein. The indirect immunofluorescent staining pattern of serum Rb188 (Fig. 8) is indistinguishable from that of serum F72, except that it does not give the reticular staining pattern at cellularization. This confirms that the Drosophila DNA cloned in $\lambda \mathrm{cs} 3$ encodes part of the $185 \mathrm{~K}$ protein associated with centrosomes and nuclei in embryos. On the other hand, antisera against the $175 \mathrm{~K}$ pURj63 fusion protein

Fig. 7. Indirect immunostaining of Drosophila embryos with affinity-purified F72 antiserum. Embryos were incubated with affinity-purified F72 antiserum (see Materials and methods) followed by rhodamine-conjugated anti-mouse IgG and Hoechst. The Hoechst-stained field (H) shows metaphase chromosomes from a blastoderm embryo and the corresponding staining with the affinitypurified antiserum (A) shows one centrosome at each spindle pole and faint staining of the mitotic spindle (cf. Fig. 1). Bar, $20 \mu \mathrm{m}$. 

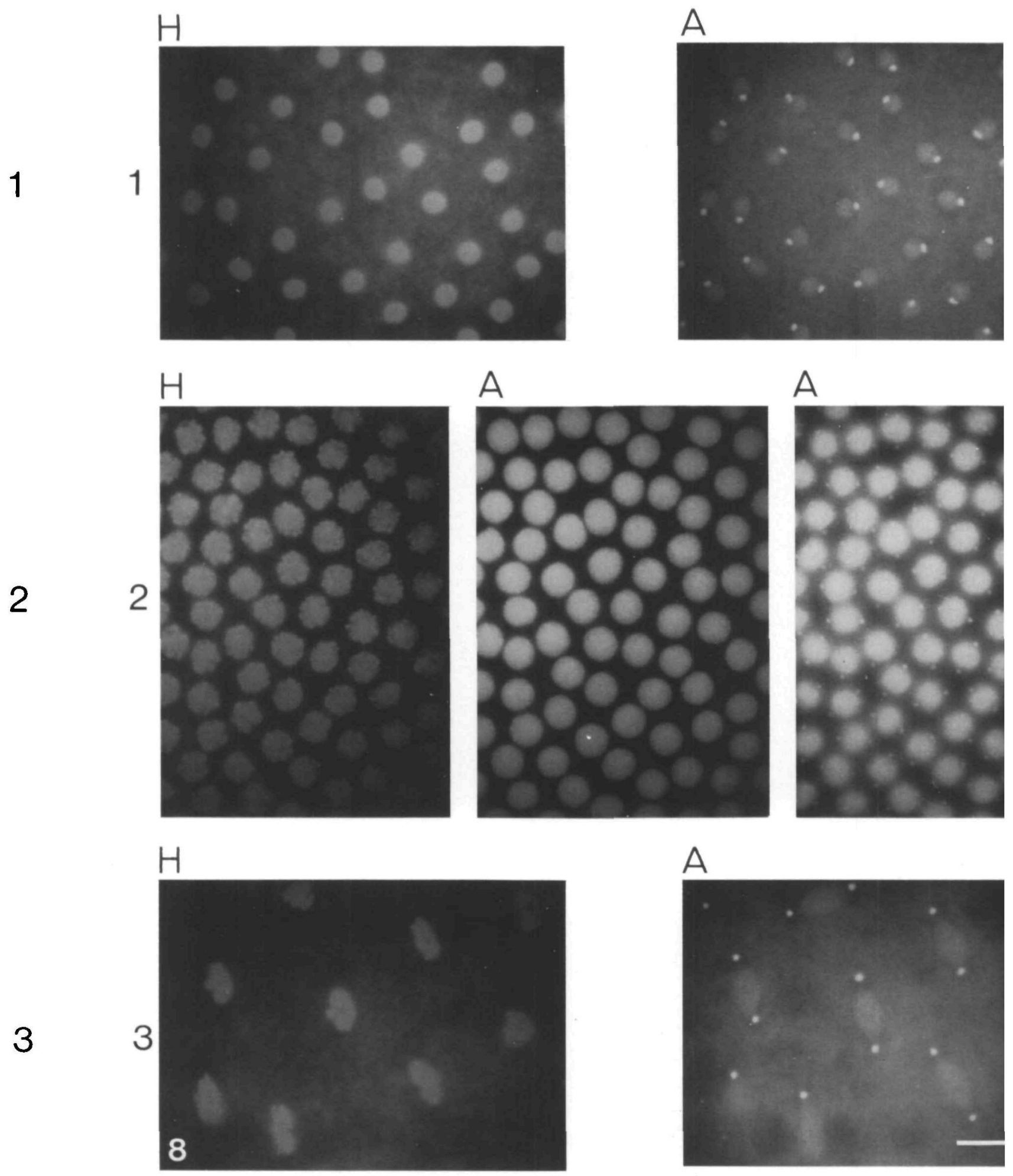

Fig. 8. Indirect immunofluorescence staining of Drosophila embryos with antiserum Rb188. Embryos were incubated in antiserum Rb188 followed by rhodamine-conjugated anti-rabbit IgG and Hoechst. Field 1, the nuclei at interphase; field 2, at prophase; and field 3, at anaphase. The staining pattern is similar to that described for antiserum F72 in Fig. 3.

Embryos immunostained with pre-immune serum showed no detectable staining of centrosomes or nuclei. Bar, $20 \mu \mathrm{m}$.

failed to recognize either the $185 \mathrm{~K}$ or $66 \mathrm{~K}$ protein on Western blots of total protein from embryos and did not give any detectable immunostaining of cleavage embryos. Thus the $\lambda \mathrm{j} 63$ fusion protein appears to have only one antigenic determinant in common with the $185 \mathrm{~K}$ protein (i.e. the Bx63 epitope). 


\section{Homologies between cloned DNAs}

In order to clarify the relationship between the $\lambda \mathrm{gt} 11$ clones selected using monoclonal antibody $\mathrm{Bx} 63$, we isolated the insert fragment from clone $\lambda \mathrm{cs} 1$, radiolabelled it with ${ }^{32} \mathrm{P}$ and used it to probe a Southern blot (Southern, 1975) of EcoRI-digested DNA from $\lambda \mathrm{j} 63$, $\lambda \operatorname{cs} 1, \lambda \operatorname{cs} 2, \lambda \operatorname{cs} 3$ and $\lambda \operatorname{cs} 4$. After washing at high stringency and exposing to X-ray film, cross-hybridization was detectable on autoradiographs between all the genomic clone inserts $(\lambda$ cs $1-4)$ but not with the cDNA clone $\lambda j 63$ (data not shown). Thus similarities detected at the DNA level correspond to those observed using an immunological approach. Hybridization of radiolabelled $\lambda \operatorname{cs} 3$ insert fragment at high stringency, to a Southern blot of Drosophila genomic DNA digested with either Eco RI, BamHI, SalI or HindIII, revealed single bands for all except the SalI digest, which showed two bands (results not shown). Hence the Drosophila $185 \mathrm{~K}$ protein recognized by $\mathrm{Bx} 63$ is probably encoded by a single-copy gene. This conclusion is supported by in situ hybridization of the $\lambda \operatorname{cs} 3$ insert to polytene chromosomes at a single site in the genome, 88E 4-8 (Fig. 9).

\section{Developmental expression of the $185 \mathrm{~K}$ Bx63 antigen gene}

We have investigated the expression of mRNA encoding the $185 \mathrm{~K} \mathrm{Bx} 63$ antigen by using radiolabelled

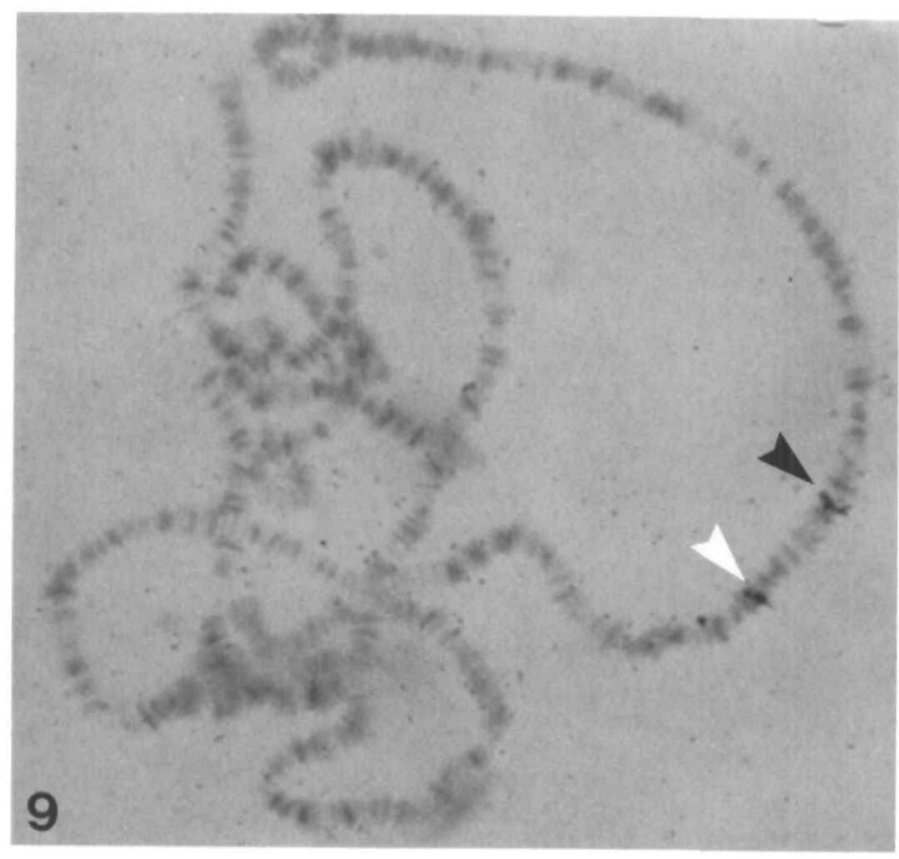

Fig. 9. Autoradiograph of D. melanogaster polytene chromosomes hybridized with radiolabelled $\lambda \mathrm{cs} 3$ DNA. The position of $\lambda \operatorname{cs} 3$ hybridization is indicated by a black arrowhead; the white arrowhead indicates the position of hybridization of cloned DNA from the rosy gene included as a positive control. insert fragment from clone $\lambda \mathrm{cs} 3$ to probe Northern blots of polyadenylated RNA from various developmental stages of Drosophila. A transcript of approximately $4.0 \times 10^{3}$ bases was detected in all developmental stages, notably in $0-16 \mathrm{~h}$ embryos and adult females (Fig. 10). As a control for loading and transfer of RNA from the different developmental stages, the filter was reprobed for actin mRNA with a cloned actin gene. The level of the transcript encoding the $185 \mathrm{~K}$ antigen relative to actin transcripts increases in $0-16 \mathrm{~h}$ embryos compared with $0-4 \mathrm{~h}$ embryos. Previous studies by Frasch (1985) have shown that the Bx63 antigens are present in abundance during the first $2 \mathrm{~h}$ of embryogenesis (see Discussion). The transcript abundance is consistent with the $185 \mathrm{~K} \mathrm{Bx} 63$ antigen being maternally supplied as protein for the early stages of embryogenesis, prior to the general activation of transcription when the cell cycle lengthens after cellularization. Similarly, the relatively high levels of transcript in adult females may reflect their role in supplying Bx63 antigen as protein to the developing eggs.

\section{Discussion}

An understanding of the mechanisms involved in mitosis can be facilitated by the cloning and molecular analysis of genes encoding components of the mitotic apparatus. One approach to the cloning of these genes is to use antibodies that recognize protein components of the mitotic apparatus to screen expression libraries. This route has been taken by Goldstein el al. (1986) to clone a gene encoding a $205 \mathrm{~K}$ microtubule-associated protein of Drosophila and by Earnshaw et al. (1987) to clone a major human centromeric antigen, CENP-B. In this report we describe the use of this approach to clone a gene encoding a protein with an apparent molecular weight of $185 \times 10^{3}$, which is associated with the centrosome in Drosophila.

Monoclonal antibody $\mathrm{Bx} 63$ has been shown to recognize two proteins with apparent molecular weights of 185 and $66\left(\times 10^{3}\right)$ in extracts of Drosophila embryos. We have conclusively demonstrated that the $185 \mathrm{~K}$ protein is associated with both the centrosome and the nucleus. The Bx63 antigens accumulate in the oocyte nucleus during oogenesis, suggesting that they are being stored for subsequent use during embryogenesis (Frasch et al. 1986). Semi-quantitative data from Western blots of total embryonic protein indicate that the amounts of the $185 \mathrm{~K}$ and $66 \mathrm{~K}$ proteins present in the embryo do not change noticeably during embryonic development (Frasch, 1985; Whitfield \& Potter, unpublished observations). On the other hand, the antigens are not detectable by immunofluorescence in the newly laid embryo, but appear to become associated with centrosomes, which increase in number some $10^{4}$-fold during development from zygote to cellular 

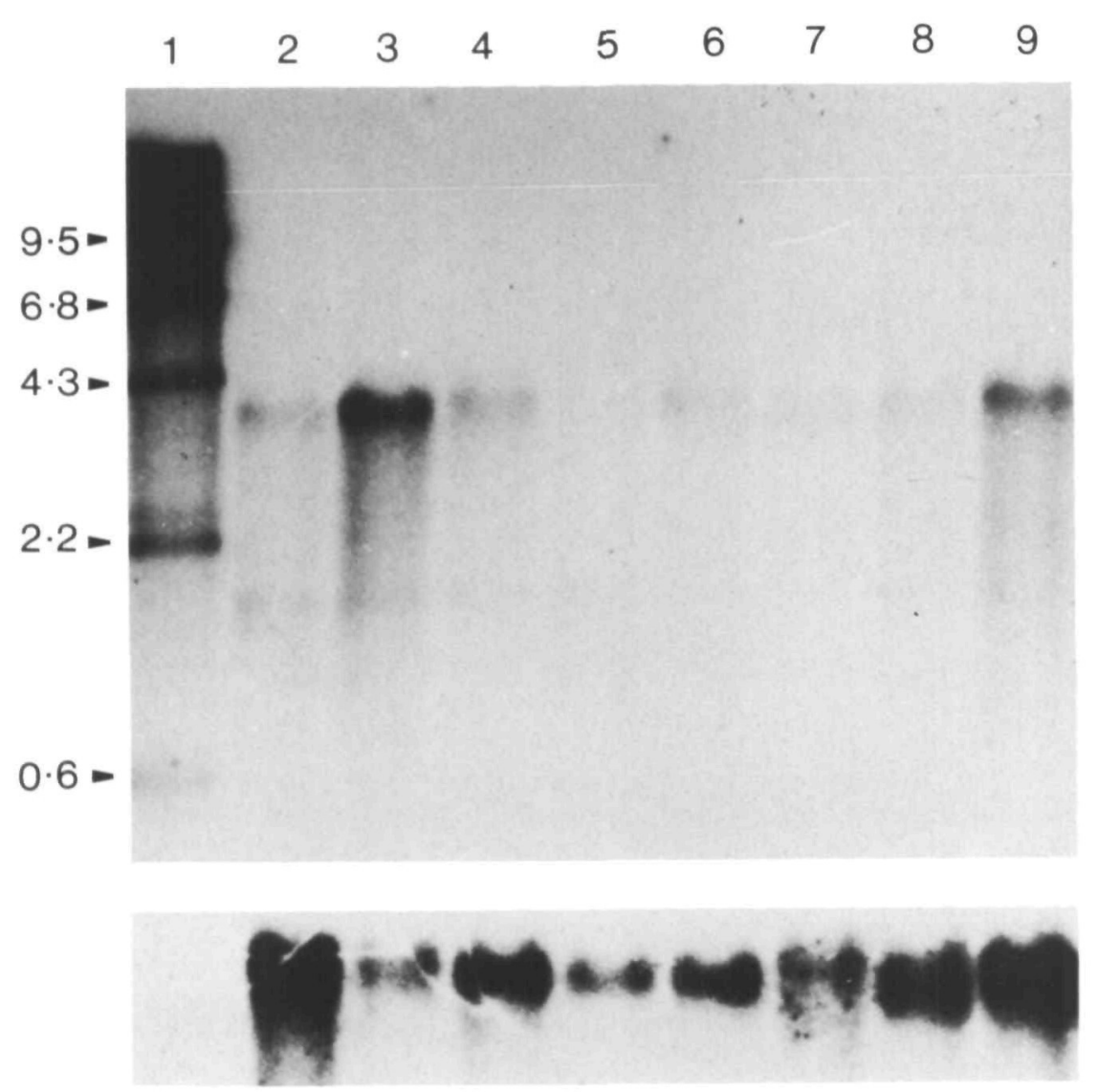

Fig. 10. Hybridization of radiolabelled insert fragment from $\lambda$ cs1 to a Northern blot of polyadenylated RNA from various developmental stages of Drosophila. Lane 1, Hind III digest of $\lambda$ DNA; lane 2, polyadenylated RNA from $0-4 \mathrm{~h}$ embryos; lane $3,0-16 \mathrm{~h}$ embryos; lane 4, first instar larvae; lane 5 , second instar larvae; lane 6 , third instar larvae; lane 7 , pupae; lane 8 , adult males; lane 9, adult females. RNA was separated on $1 \%$ agarose gels containing $2 \cdot 2 \mathrm{M}$ formaldehyde. The same filter reprobed for actin is shown below for comparison of loading between tracks. Marker sizes are indicated in kilobases. blastoderm. Consequently, the maternally derived Bx63 antigen must be present in early embryos in a form that is either not recognized or is too diffuse to be detected by immunostaining with the Bx63, F72 or Rb188 antibodies. Further studies will be necessary to discover whether the Bx63 antigens are phosphorylated, or undergo any other post-translational modifications that might account for their changing distribution during embryogenesis.

The Bx63 antibody stains the centrosomes associated with all mitotically active nuclei, but centrosomal staining is not detectable adjacent to yolk nuclei that have ceased dividing and become polyploid (Frasch et al. 1986). Centrosomal staining is evident during all the early divisions but nuclear staining is not observed in cleavage embryos until the beginning of the blastoderm stage at nuclear division cycle 10 . Although the $185 \mathrm{~K} \mathrm{Bx} 63$ antigen is associated with the centrosome, this does not necessarily mean that it has a direct role in the ability of the centrosome to nucleate microtubules. Cyclic-AMP-dependent protein kinase (type II), for example, has been shown to be associated with the centrosome and Golgi complex in mammalian cells (Nigg et al. 1985). An ultrastructural analysis of nuclear division in Drosophila embryos has shown that the nuclear envelope ruptures around the spindle poles at the onset of prometaphase, but remains intact elsewhere throughout mitosis (Stafstrom \& Staehelin, 1984). A second envelope forms around the nuclear envelope during prometaphase/metaphase, creating a double-layered structure referred to as the spindle envelope, which persists until early interphase. The nuclear staining observed in late blastoderm embryos after immunostaining with antiserum Rb188 is clearly delimited from the cytoplasm of the embryo during mitosis, and may be confined within the spindle envelope. We hope to define the ultrastructural distribution of the $\mathrm{B} \times 63$ antigens using immunoelectron microscopy.

The successful identification of cloned DNAs as those encoding the $185 \mathrm{~K} \mathrm{Bx} 63$ antigen has depended upon having a serum, F72, that recognizes epitopes present on the antigen other than that recognized by the Bx63 monoclonal antibody. The $\mathrm{F} 72$ serum was raised against a preparation enriched for the $185 \mathrm{~K}$ and 66K Bx63 antigens (see Results and Fig. 3). We were surprised at the low abundance of the $66 \mathrm{~K}$ protein in this preparation relative to its strong immune signal on Western blotting. This low abundance could explain the absence of an immune response to this protein in the F72 serum. Since we have been unable to prepare antisera that recognize the $66 \mathrm{~K}$ protein, its cellular location remains uncertain. However, as two polyclonal antisera (F72 and Rb188) have been prepared that recognize the $185 \mathrm{~K}$ protein but not the $66 \mathrm{~K}$ protein, it seems that these proteins are not closely related.

It is unclear why there was no detectable immune response against the $55 \mathrm{~K}$ and $46 \mathrm{~K}$ proteins that co- 
purify with the $\mathrm{B} \times 63$ antigens as these constitute a major proportion of the preparation. We are currently attempting to make antisera against each of these proteins, since their association with the centrosomal antigen may have biological significance. An antiserum raised against the $200 \mathrm{~K}$ protein from this preparation gave a reticular staining pattern in cellularized blastoderm embryos, and did not appear to have any association with either the centrosome or nucleus.

The gene encoding the $185 \mathrm{~K} \mathrm{Bx} 63$ antigen appears to occur as a single copy in the Drosophila genome located in region $88 \mathrm{E}(4-8)$ on the right arm of chromosome 3. To our knowledge few mutant genes that map to this region have been described. We are now in a position to begin a genetic analysis of this gene as one route towards discovery of its function in vivo.

This work was supported by a grant from the Cancer Research Campaign (CRC) for which we are most grateful. D.M.G. holds a Career Development Award from the CRC and received short term fellowships from EMBO that enabled him to visit Tübingen in July 1984 and May 1985. S.E.M. held an MRC Research Studentship. We would like to thank Claudio Sunkel for carrying out the in situ hybridization experiment shown in Fig. 9, and Nicola Williamson for assistance with the early stages of this work. Herbert Jäckle and Reinhard Schuh introduced us to the techniques of screening $\lambda$ gt 11 libraries with antibodies and M. Wilcox and G. Pflugfelder provided libraries.

\section{References}

Brenner, S., Branch, A., Meredith, S. \& Burns, M. W. (1977). The absence of centrioles from spindle poles of rat kangaroo $\left(\mathrm{PtK}_{2}\right)$ cells undergoing meiotic-like reduction in vitro. J. Cell Biol. 72, 368-379.

Calarco-Gillam, P. D., Siebert, M. C., Hubble, R., Mirchison, T. \& Kirschner, M. (1983). Centrosome development in early mouse embryos as defined by an autoantibody against pericentriolar material. Cell 35, 621-629.

Connolly, J. A. \& Kalnins, V. I. (1978). Visualization of centrioles and basal bodies by fluorescent staining with non-immune rabbit sera. F. Cell Biol. 79, 526-532.

Debec, A., Szollosi, A. \& Szollosı, D. (1982). A Drosophila melanogaster cell line lacking centrioles. Biol. Cell 44, 133-138.

DenhardT, D. T. (1966). A membrane-filter technique for the detection of complementary DNA. Biochem. biophys. Res. Commun. 23, 641-646.

Dequin, R., Saumweber, H. \& Sedat, J. W. (1984). Proteins shifting from the cytoplasm into the nuclei during early embryogenesis of Drosophila melanogaster. Devl Biol. 104, 37-48.

Earnshaw, W. C., Sullivan, K. F., Machlin, P. S., Cooke, C. A., Kaiser, D. A., Pollard, T. D., Rothfield, N. F. \& Cleveland, D. W. (1987). Molecular cloning of cDNA for CENP-B, the major human centromere autoantigen. . Cell Biol. 104, 817-829.

Feinberg, A. P. \& Vogelstein, B. (1983). A technique for radiolabelling restriction endonuclease fragments to high specific activity. Analyt. Biochem. 132, 6-13.

Feinberg, F. R. \& Vogelstein, B. (1984). Addendum. Analyt. Biochem. 137, 266-267.

Frankel, F. R. (1976). Organization and energydependent growth of microtubules in cells. Proc. natn. Acad. Sci. U.S.A. 73, 2798-2802.

FRASCH, M. (1985). Charakterisierung chromatinassoziierter kernproteine von Drosophila melanogaster mit hilfe monoklonaler antikörper. Doctoral Dissertation. Eberhard-Karls-Universität Tübingen, FDR.

Frasch, M., Glover, D. M. \& Saumweber, H. (1986). Nuclear antigens follow different pathways into daughter nuclei during mitosis in early Drosophila embryos. 7. Cell Sci. 82, 155-172.

Freeman, M. \& Glover, D. M. (1987). The gmu mutation of Drosophila causes inappropriate DNA synthesis in unfertilized and fertilized eggs. Genes $\sigma^{\circ}$ Der. 1 , 924-930.

Freeman, M., Nusslein-Volhard, C. \& Glover, D. M. (1986). The dissociation of nuclear division and centrosomal division in gnu, a mutation causing giant nuclei in Drosophila. Cell 46, 457-468.

Fuchs, J.-P., Giloh, H., Kuo, C.-H., SAumweber, H. \& SEDAT, J. (1983). Nuclear structure: determination of the fate of the nuclear envelope in Drosophila embryos using monoclonal antibodies. Y. Cell Sci. 64, 331-349.

Giloh, H. \& Sedat, J. W. (1982). Fluorescence microscopy: reduced photobleaching of rhodamine and fluorescein protein conjugates by $n$-propyl gallate. Science 217, 1252-1255.

Goldstein, L. S. B., Laymon, R. A. \& Mclntosh, J. R. (1986). A microtubule-associated protein in Drosophila melanogaster: identification, characterization, and isolation of coding sequences. Y. Cell Biol. 102, 2076-2087.

Gosti-Testu, F., Marty, M.-C., Berges, J., Maunoury, R. \& BORNENS, M. (1986). Identification of centrosomal proteins in a human lymphoblastic cell line. EMBOY. 5(10), 2545-2550.

Gould, R. R. \& BoRISY, G. G. (1977). The pericentriolar material in Chinese hamster ovary cells nucleates microtubule formation. 9. Cell Biol. 73, 601-615.

Huynh, T. V., Young, R. A. \& Davis, R. W. (1985). Constructing and screening cDNA libraries in $\lambda \mathrm{gt} 10$ and $\lambda$ gt11. In DNA Cloning: a Practical Approach, vol. I (ed. D. M. Glover), pp. 49-78. Oxford, Washington, DC: IRL Press.

KARR, T. L. \& Alberts, B. M. (1986). Organization of the cytoskeleton in early Drosophila embryos. Y. Cell Biol. 102, 1494-1509.

Kuriyama, R. \& BorisY, G. G. (1981). Centriole cycle in Chinese hamster ovary cells as determined by wholemount electron microscopy. F. Cell Biol. 91, 814-821.

KurIYAma, R. \& BorisY, G. G. (1985). Identification of molecular components of the centrosphere in the mitotic spindle of sea urchin eggs. F. Cell Biol. 101, 524-530. 
LAEMMLI, U. K. (1970). Cleavage of structural proteins during the assembly of the head of bacteriophage $\mathrm{T} 4$. Nature, lond. 227, 680-685.

Messing, J., Gronenborn, B., Muller-Hill., B. \& Ilofschneider, P. H. (1977). Filamentous coliphage $\mathrm{M} 13$ as a cloning vehicle: insertion of a hindII fragment of the lac regulatory region in $\mathrm{M} 13$ replicative form in vitro. Proc. natll. Acad. Sci. U.S.A. 74, 3642-3646.

MILLAR, S. (1987). Polytenization and mitosis in Dipteran flies. Ph.D. thesis, Imperial College, University of London, UK.

Mitchison, T. J. \& Kirschner, M. W. (1984). Microtubule assembly nucleated by isolated centrosomes. Nature, Lond. 312, 232-236.

Mrtchison, T. J. \& Sedat, J. W. (1983). Localisation of antigenic determinants in whole Drosophila embryos Dezl Biol. 99, 261-264.

Nigig, E. A., Schafer, G., Hilz, H. \& Eppenberger, H. M. (1985). Cyclic-AMP-dependent protein kinase type II is associated with the golgi complex and with centrosomes. (ell 41, 1039-1051.

NigG, E. A., WAlter, G. \& Singer, S. J. (1982). On the nature of crossreactions observed with antibodies directed to defined epitopes. Proc. natn. Acad. Sci. U.S.A. 79, 5939-5943.

Osborn, M. \& Weber, K. (1976). Cytoplasmic microtubules in tissue culture cells appear to grow from an organizing structure towards the plasma membrane. Proc. natn. Acad. Sci. U.S.A. 73, 867-871.

PARDUe, M. L. (1986). In situ hybridization to DNA of chromosomes and nuclei. In Drosophila a Practical Approach (ed. D. B. Roberts), pp. 111-137. Oxford, Washington, DC: IRL. Press.

Rave, N., Chkventuakov, R. \& Boedtker, H. (1979). Identification of procollagen $m R N A s$ transferred to diazobenzyloxymethyl paper from formaldehyde-agarose gels. Nucl. Acids Res. 6, 3559-3567.

Ring, D., Hubble, R., Caput, D. \& Kirschner, M. (1980). Isolation of microtubule organizing centers from mouse neuroblastoma cells. In Microtubules and Microlubule Inhibilors (ed. M. DeBrabander \& J. DeMey), pp. 297-309. Amsterdam: Elsevier/NorthIlolland.

Robins, E., Jentzsch, G. \& Micali, A. (1968). The centriole cycle in synchronized HeLa cells. $\%$. ('ell Biol. 36, 329-339.
RUTHer, U. \& MÜller-Hill, B. (1983). Easy identification of cDNA clones. EMBBO Y. 2, 1791-1794.

Schneider, C., Newman, R., Sutherland, D. R., Asser, U. \& Graves, U. F. (1982). One step purification of membrane proteins using a high efficiency immunomatrix. \%. biol. Chem. 257, 10766-10769.

Simanis, V. \& LANE, D. P. (1985). An immunoaffinity purification procedure for SV40 large T antigen. Iirology' 144, 88-100.

SNYDER, J. A. \& MCINTOSH, J. R. (1975). Initiation and growth of microtubules from mitotic centers in lysed mammalian cells. J. Cell Biol. 67, 744-760.

Southern, E. M. (1975). Detection of specific sequences among DNA fragments separated by gel electrophoresis. J. molec. Biol. 98, 503-517.

Stafstrom, J. P. \& Staehelin, L. A. (1984). Dynamics of the nuclear envelope and of the nuclear pore complexes during mitosis in the Drosophila embrvo. Eur. Y. Cell Biol. 34, 179-189.

Sunkel, C. E. \& Glover, D. M. (1987). polo, a mitotic mutant of Drosophila displaying abnormal spindle poles. y. Cell Sci. 89, 25-38.

Thomas, P. S. (1980). Hybridization of denatured RNA and small DNA fragments transferred to nitrocellulose. Proc. natn. Acad. Sci. U.S.A. 77, 5201-5205.

Towbin, H., Staehelin, T. \& Gordon, J. (1979). Electrophoretic transfer of proteins from polyacrylamide gels to nitrocellulose sheets: procedure and some applications. Proc. Matn. Acad. Sci. U.S.A. 76, $4350-4354$.

Vorobjev, I. A. \& Chentsov, Yu. S. (1982). Centrioles in the cell cycle. 1. Epithelial cells. $\mathcal{Y}$. Cell Biol. 98, 938-949.

Warn, R. M., BUllard, R. \& Magrath, R. (1980). Changes in the distribution of cortical myosin during the cellularisation of the Drosophila embryo. Y. Embryol. exp. Morph. 57, 167-176.

YounG, R. A. \& DAvis, R. W. (1983a). Efficient isolation of genes by using antibody probes. Proc. natn. Acad. Sci. U.S.A. 80, 1194-1198.

Young, R. A. \& DAvis, R. W. (1983b). Yeast RNA polymerase II genes: isolation with antibody probes. Science 222, 778-782.

(Receired 20 October 1987 - Accepted 9 December 1987) 